\title{
KEABSAHAAN SERTIPIKAT HAK MILIK ATAS TANAHH BERDASARKAN UUPA DAN PERATURAN PEMERINTAH NOMOR 24 TAHUN 1997 TENTANG PENDAFTRAN TANAH
}

\author{
Emeralda Leticia \\ (Mahasiswa Program Strata Satu Fakultas Hukum Universitas Tarumanagara angkatan 2015 dengan \\ Nomor Induk Mahasiswi: 205150062) \\ (emeraldaleticia@gmail.com)
}

Dr. Hasni, S.H., M.H.

(Coresponding Author)

(Dosen Fakultas Hukum Universitas Tarumanagara. Meraih Sarjana Law pada Fakultas Hukum Universitas Krisnadwipayana Magister Hukum pada Fakultas Law Universitas Indonesia)

(E-mail : hasni@fh.untar.ac.id)

\begin{abstract}
The certificate is a proof of ownership that is strong, this certificate comes from land rights which are the right to use and exploit the land which it occupies. Rights to land are also divided into Property Rights, Cultivation Rights, Building Use Rights, Use Rights, Rental Rights for Buildings, Use Rights and Temporary Land Rights. In this case the author will only explain the ownership rights related to legal issues, namely the right of ownership. Property rights are the strongest and most complete rights that humans can have. This right is obtained based on land registration. Own land registration is carried out by the authorized party, namely the National Land Agency. But in this case on the island of Pari, the certificate was declared maladministration by the ORI which caused the author to write about the validity of the certificate of land ownership based on law. With the formulation of the problem, how is the validity of the Certificate of Property Ownership according to uupa and Government Regulation Number 24 of 1997 related to the statement of maladministration by the ORI? and What are the legal consequences for certificate holders due to the administrative maladministration? By using explanatory research methods. In this case the researcher gets the result that in the process of land registration the measurement process is not carried out which is one of the requirements to obtain physical data and there is no announcements must be made because to provide an opportunity to file an objection.
\end{abstract}

Keywords: certificate, land, maladministration 


\section{PENDAHULUAN}

\section{A. Latar Belakang}

Sertipikat Tanahh adalah hasil akhir dari kegiatan Pendaftran tanahh, Sertipikat tanahh memiliki berbagai fungsi bagi pemegang haknya, dan fungsinya itu tidak dpat digantikaan dengan benda lain. Sertipikat hak atas tanahh merupakan alat pembuktian yang kuat yang merupakan fungsi utama sebagaimana disebut dalam Pasal 19 ayat (2) huruf c UUPA. Sertipikat hak atas tanahh memberikan kepercayaan bagi pihak bank/kreditor untuk memberikan pinjaman uang kepada pemiliknya, yang mempermudah pemegang hak untuk dapat menerima pinjaman modal. Serta adanya Sertipikat hak atas tanahh membuktikan bahwa tanahh yang bersangkutan telah terdaftar dalam Kantor Agraria yang membuat data ini sangat penting untuk perencanaan kegiatan pembangunan ${ }^{1)}$

Sertipikat ini berasal dari hak atas tanahh yang merupakan hak untuk menggunakan dan memanfaati dari tanahh yang dihakinya. Pengertian tanahh juga diatur dalam Pasal 4 UUPA dinyatakan sebagai berikut.

"Atas dasar hak menguasai dari negara sebagai yang dimaksud dalam Pasal 2 ditentukan adanya macam-macam hak atas permukaan bumi, yang disebut tanahh, yang dapat diberikan kepada dan dipunyai oleh orangorang, baik sendiri maupun bersama-sama dengan orang lain serta badan badan hukum."2)

Dengan demikian, jelaslah bahwa tanahh dalam pengertian yuridis adalah permukaan bumi. Hak atas permukaan bumi atau tanahh adalah hak yang memberikan wewenang kepada pemilik haknya untuk mempergunakan atau

\footnotetext{
1) Adrian Sutedi, Sertipikat Hak Atas Tanahh, (Jakarta: Sinar Grafika, 2014), hal. 57.
}

2) Supriadi, Hukum Agraria, Cetakan ke-2, (Jakarta: Sinar Grafika,2008), hal. 3 


\section{:-: Jurnal Huknm Adigamå}

Emeralda Leticia \& Hasni

Keabsahan Sertipikat

Hak Milik Atas Tanah Berdasarkan

UUPA dan Peraturan Pemerintah

Nomor 24 Tahun 1997

tentang Pendaftaran Tanah

mengeksploitasi ttanahh. Tanahh dalam pengertian yuridis adalah permukaan

bumi, sedangkan hak atas tanahh adalah hak yang memberikan wewenang kepada pemegang haknya untuk mempergunakan atau mengambil manfaat dari tanahh yang dihakinya. ${ }^{3)}$ Hak atas tanahhh bersumber dari hak menguasai dari negaraa atas tanahh dapat diberikan kepada perseorangan baik warga negara Indonesia maupun warga negara bukan indonesia, sekelompok orang secara bersama-sama, dan badan hukum baik badan hukum privat maupun badan hukum publik. ${ }^{4)}$

Hak-Hak atas tanahh juga terbagi menjadi Hak Milik, Hak Guna Usaaha, Hak Gunna Bangunaan, Hak Paakai, Hak Sewaa untuk Bangunan, Hak Pakai dan Hak Atas Tanahh yang Bersifat Sementara. Hak-hak tersebut menghasilkan sertipikat. Sertipikat merupakan alat bukti pemilikan hak yangkuat, yang jika tidak ada pembuktian yang mengatakan sebaliknya maka sertipikat tersebut berlaku dan jika terdapat bantahan atas sertipikat tersebut maka sertipikat tersebut dapat digugat ke pengadilan. Sertipikat diatur dalam Peraturan Pemerintahh No.24 Tahun 1997 tentang pendaftaran tanahh, sertipikat sendiri dibuat oleh pejabat yang berwenang yaitu BPN. BPN merupakan Badan Pertanahhan Nasional. Sertipikat sendiri merupakan juga hasil pendaftaran tanahh. Pengertian pendaftarn tanahh dalam Peraturan Pemerintahh No. 24 Tahun 1997 merupakan penyempurnaan dari ruang lingkup kegiatan Pendaftran tanah berdasarkan Pasal 19 ayat (2) Peraturan Pemerintahh No. 10 Tahun 1961 yang hanya meliputi: "Pengukuran, Perpetaan dan Pembukuan Tanah, Pendaftaran dan Peralihan hak atas tanah serta

${ }^{3)}$ Urip Santoso, Hukum Agraria dan Hak-Hak Atas Tanahh, Cetakan ke-5. (Jakarta: Kencana Pranada Media Group, 2009), hal.10

${ }^{4)}$ Supriadi, Op.Cit.,hal. 87. 


\section{遭 Jurnal Huknum Adigamä}

Emeralda Leticia \& Hasni

Keabsahan Sertipikat

Hak Milik Atas Tanah Berdasarkan

UUPA dan Peraturan Pemerintah

Nomor 24 Tahun 1997

tentang Pendaftaran Tanah

pemberian tanda bukti hak sebagai alat pembuktian yang kuat ${ }^{5}$. Pendaftaran tanah merupakan tugas pemerintahan yang diselenggarakan dalam rangka menjamin kepastian hukum dii bidang pertanahan. ${ }^{6}$ Pendaftaran tanah terbagi menjadi 2 yaitu, secara sistematik and secara sporadik. Pendaftran tanahh secara sporadik adalah Pendaftaran yang dilakukan dan diajukan oleh pihak yang berkepentingan dan secara sporadik, Pendaftaran tanah yang dilakukan berdasarkan permintaan pemerintah yang dilakukan secara menyeluruh dalam suatu kelurahan atau wilayah. Pendaftaran tanahh secara siistematik dilaksanakan melalui yang dimaksud menurut Pasal 1 angka 8 Peraturan Pemerintah No. 24 Tahun 1997, adalah kegiatan yang dilaksanakan dalam rangka proses Pendaftaran tanah untuk pertama kali, meliputi pengumpulan dan penetapan kebenaran data fisik dan data yuridis mengenai satu atau beberapa objek Pendaftaran tanah untuk keperluan pendaftarannya ${ }^{7)}$. Pendaftaran tanah secara sporadik adalah pemohon Pendaftaran tanah baik yang bersifat kesendirian (perseorangan) atau masal (kolektif) menyiapkan berkas-berkas yang dibutuhkan, datang ke Kantor Pertanahan Kabupten/Kota setempat untuk mengajukan permohonan agar tanahhnya didaftar (disertipikatkan), dan menanggung seluruh biaya yang dibebankan kepada pemohon. ${ }^{8)}$

Peneliti dalam hal jurnal ini menggunakan Pendaftaran secara sporadik karena berdasarkan kasus yang peneliti teliti. Kasus Pulau Pari yang peneliti pakai dimana sertipikat tersebut dinyatakan maladministrasi oleh ORI. Peneliti menggunakan Prosedur Pendaftaran Tanah secara Sporadik menurut Peraturan

5) Mhd. Yamin Lubis dan Abd. Rahim Lubis. Hukum Pendaftran Tanahh, (Bandung.: Mandar Maju, 2008). hal. 15.

6) Boedi Harsono, Hukum Agraria Indonesia, (Jakarta: Djambatan, 2008). hal. 472.

7) Urip Santoso, Pendaftran Op.Cit., hal. 136.

8) Ibid., hal. 172. 
Pemerintah No. 24 tahun 1997 yaitu Pendaftaran tanah yang dilakukan atas permintaan pihak yang berkepentingan (Pasal 13 Ayat (4) Peraturan Pemerintah No. 24 tahun 1997) dalam hal ini pihak yang berkepentingan adalah pemegang hak dan pihak atau pihak-pihak lain yang mempunyai kepentingan mengenai bidang tanahh. Pembuatan Peta Dasar Pendaftaran (Pasal 15 dan Pasal 16 Peraturan Pemerintah No. 24 tahun 1997), yaitu pengukuran untuk pembuatan peta dasar Pendaftran diikatkan dengan titik-titik dasar teknik nasional sebagai kerangka dasarnya, peta dasar Pendaftaran menjadi dasar untuk pembuatan peta Pendaftaran.

Hasil pengumpulan dan penelitian data yuridis beserta peta bidang atau bidang-bidang tanahh yang bersangkutan sebagai hasil pengukuran diumumkan selama 60 (enam puluh) hari untuk memberikan kesempatan kepada pihak yang berkepentingan mengajukan keberatan. Setelah dilakukan pengumuman, maka dilakukan pengesahan hasil pengumuman penelitian data fisik dan data yuridis (Pasal 28 Peraturan Pemerintah No. 24 tahun 1997) dilakukan setelah jangka waktu pengumuman berakhir, data fisik dan data yuridis disahkan dengan suatu berita acara, berita acara menjadi dasar untuk pembukuan hak atas tanahh. Pembukuan Hak (Pasal 29 dan Pasal 30 Peraturan Pemerintahh No. 24 tahun 1997) yang dibukukan dan ditandatangani oleh yaitu dalam pembukuan hak pembatasan-pembatasan yang berangkutan dengan hak tersebut, termasuk pembatasan dalam pemindahan hak, pembatasan dalam penggunaan tanahh menyangkut garis sempadan pantai dan pembatasan penggunaan tanahh hak dalam kawasan industri, juga dicatat yang berkesimpulan semua yang menyangkut mengenai hak tersebut akan dibukukan dan ditandatangani oleh Kepala Kantor Pertanahhan Kabupaten/Kota setempat. Setelah dilakukan pembukuan hak maka dilakukan penerbitan Sertipikat (Pasal 31 Peraturan Pemerintahh No. 24 Tahun 1997). Penerbitan Sertipikat 
diserahkan kepada pemegang hak atau kuasanya dan penandatanganan Sertipikat dilakukan oleh Kepala Kantor Pertanahhan Kabupaten/Kota setempat. ${ }^{9}$ Setelah dilakukan pembukuan hak maka dilakukan penerbitan Sertipikat (Pasal 31 Peraturan Pemerintahh No. 24 Tahun 1997). Penerbitan Sertipikat diserahkan kepada pemegang hak atau kuasanya dan penandatanganan Sertipikat dilakukan oleh Kepala Kantor Pertanahhan Kabupaten/Kota setempat. ${ }^{10}$

BPN memiliki kewenangan untuk melaksanakan segala sesuatu yang berkaitan dengan tanahh yang memiliki fungsi dan kepentingan bagi publik dan privat lebih tepat yaitu masyarakat. Dari pengukuran sampai mengeluarkan Sertipikat adalah tugasnya BPN dan badan yang mengawasi BPN dalam menjalankan tugas adalah lembaga negara yang bernama ORI, berdasarkan UU No. 37 Tahun 2008 tentang ORI, Psal 1 Ayat (1) mengatakan bahwa ORI merupakan Lembaga Pemerintah yang mempunyai kewenangan mengawasi Penyelenggaran Pelayanan Publik baik yang diselenggarakan oleh Badan Usaha Milik Negara, Badan Usaha Milik Daerah, dan Badan Hukum miliik Negara serta Badan Swasta atau perseorangan individu yang diberi tugas menyelenggarakan pelayanan umum tertentu yang sebagian atau seluruh dananya bersumber dari anggaran pendapatan dan belanja Negara dan/atau anggaran pendapatan dan belanja daerah. Selain itu tugas dari ORI adalah menerima laporan atas dugaan maladministrassi dalam penyelenggaraan pelayanann publik, melakukan pengecekan subtansi atas lporan, menindak lanjuti laporan yang tercakup dalam ruang lingkup kewenangan ORI, melakukan pemeriksaan atas penemuan sendiri terhadap dugaan maladministrasi dalam penyelenggaraan pelayanan umum, melakukan kordinasi

\footnotetext{
${ }^{9}$ Urip Santoso.,Pendaftran Op.Cit., hal. 175 - 183.

${ }^{10}$ Urip Santoso.,Pendaftran Op.Cit., hal. 175 - 183.
} 
dan kerja sama dengan lembaga negara atau lembaga pemerintahaan lainya serta lembaga kemasyarakaatan dan perseorngan, membangun jaringann kerja, melakukan upaya pencegahaan maladministrasi dalam penyelengaraan pelayanan umum, dan melakukan tugas lainnya yang diberikan oleh UndngUndang. ${ }^{11)}$

Sesuai dengan tugasnya maka ORI mengawasi lembaga pemerintahan yang melakukan maladministrasi BPN akan diawasi oleh ORI dalam melakukan tugasnya yaitu salah satunya menerbitkan Sertipikat dalam hal ini ORI akan mengawasinya jika terjadi maladministrasi dalam menjalankan tugasnya. Maladministrasi itu sendiri adalah perilaku atau perbuaatan melawan hokum, melampaui wewenan/g, menggunakan wewenng untuk tujuan lain dari yang menjadi wewenang tersebut, termasuk kegagalan atau pengabaiaan kewajibaan hokum dalam penyelenggaraan pelayanan umum yang dilakukan oleh penyelenggara negara dan pemerintahan, termasuk perseorangan yang membantu government memberikan pelayanan publik yang menimbulkan kerugian materiiil dan/atau imateril bagi masyarakat dan orang perseorangan. Sesuai dengan teori maladministrasi yang dijelaskan, maladministrasi adalah melakukan hal yang dilarang menjadi tujuan dengan mengorbankan segala sesuatu yang perlu walaupun menyangkut mengenai kepentingan umum salah satunya maladministrasi itu menjadi masalah yang meresahkan masyarakat, keresahan yang muncul itu yang akan menjadi permasalahan. BPN telah mengeluarkan 62 Sertipikat Hak Miliik yang bertentangan dengan prosedur yang diatur dalam ketentuan Pasal 18 Ayat (1), (2), (3) dan (4) serta Pasal 26 Ayat (1), (2) dan (3) PP 24/1997 tentang Pendaftran Tanahh serta terjadinya penyalahgunaan wewenang karena didalam proses tidak ada pengukuran yang diinformasikan atau tidak diketahui warga pulau pari dan tidak ada

11) Undang-Undang No. 37 Tahun 2008 tentang ORI Republik Indonesia, Pasal 7 
pengumuman mengenai hasil pengukuran yang membuat warga tidak dapat menyatakan keberatan, dan terjadinya pengabaian fungsi sosial tanahh dan terjadinya monopoli sehingga penulis ingin mengangkat kasus ini menjadi tugas akhir penulis yang dimana penulis merasakan bahwa harus ditindaklanjutkan dan dapat membawa kemudahan bagi pembaca.

Oleh karena itu penulis tertariik untuk mengangkat kasus ini yang berjudul: "Keabsahan Sertipikat Tanahh Hak Milik berdasarkan UUPA dan Peraturaan Pemerintahh No. 24 tahun 1997 tentang Pendaftran Tanahh”.

Penulis menggunakan rumusan masalah yang terdapat di dalam permasalahan karena ingin mengetahui kepastian hukum akan keabsahaan Sertipikat yang dinyatakan maladministrasi akibat untuk para pihak yang bersangkutan dan penulis sendiri menggunakan kasus ini karena penulis dalam hal ini tertarik atas kasus maladministrasi yang terjadi di pulau pari tersebut.

\section{B. Perumusan Masalah}

1. Bagaimana Keabsahaan Sertipikat Hak Milik menurut UUPA dan Peraturan Pemerintahh N0m0r 24 Tahun 1997 terkait pernyataan maladministrasi oleh ORI?

2. Bagaimana Konsekuensi hukum bagi pemegang Sertipikat akibat pernyataan maladministrasi?

\section{Metode Penelitian}

Penelitian (research) berarti pencarian kembali. Pencarian yang dimaksud adalah pencarian terhadap pengetahuaan yang benarr (ilmiah), karena hasil dari pencarian ini aakan dipkai untuk menjawab permasalaahan tertentu. ${ }^{12)}$ Pada dasarrnya penelitiaan hokum adalah suata kegiattan $k n O w-h 0 w$

\footnotetext{
${ }^{12)}$ Amiruddin dan H.Zainal Asikin, Pengantar Metode Penelitian Hukum, (Jakarta: PT RajaGrafindo Persada, 2006), hal. 19.
} 
dalam ilmu hukum, bukan sekadar knOw-abOut. Sebagai kegiatan knOw-hOw, peneliitian hokum dilakukan untuk memecahkan isu hukum yang dihadapi. ${ }^{13)}$ Penelitiaan hukum merupakan salah satu cara untuk mengidentifikasi masalah hukum dan menganalisis hukum dengan mengunakan metode sebagai berikut:

1. Jenis penelitian

Jenis penelitian yang digunakan dalam penelitian hukom adalah eksplanatoris, penelitian eksplanatoris menurut Sugiyono merupakan penelitian yang digunakan untuk mendapatkan dat4 dari tempat tertentu, tetapi peneliti melakukan perlakuaan dalam pengumpulaan data, misalnya mengedarkan question, tes, interview and the others. ${ }^{14}$

\section{Sifat Penelitian}

Sifat penelitian terbagi menjadi 3 yaitu: penelitian yang bersifat eksploraatif, penelitian yang bersifat deskrptif, dan penelitian yang bersifat eksplanatf. ${ }^{15}$ ) Peneliti menggunakan penelitian yang bersifat eksplantif. Penelitian eksplanatif adalah peneliti menjelaskan keadaan apa adanya tentang suatu peristiwa hukom atau keadaan hokum. Peristiwa hukuum itu sendiri adalah peristiwa keadaaan yang beraspek hukum, terjadi di suato tempt tetentu. ${ }^{16)}$

\section{Jenis dan Teknik Pengumpulan Bahan Hukum}

13) Peter Mahmud Marzuki, Penelitian Hukum, (Jakarta: Kencana Prenada Media Group, 2016) hal. 60.

14) Sugiyono. Metode Penelitian Pendidikan Pendekatan Kuantitatif, Kualitatif, dan R\&D. (Bandung: Alfabeta, 2013) hall. 6

15) Ibid.,hal.26

16) Dr. I Made Pasek Diantha, Metode Penelitian Hukum Normatif dalam Justifikasi Teori Hukum, (Jakarta: Kencana Prenada Media Group, 2016). hal. 152. 
Jenis Penelitian yang digunakan dalam penelitian ini adalaah penelitan hokum n0rmatif. Penelitiaan hokum norrmatif adalah menelitii hokum dari perspektiif internal with obyek penelitiannya adalah norma hoakum. Penelitian Normatif berfungsi untuk memberi argumentation yuridis ketika terjadi kek0songan, kekaburaan dan konflik norm. ${ }^{17}$

Untuk memecahhkan isuu hukum dan sekaligus memberikan preskripsii mengenai apa yang seyogianya, diperlukan sumber sumberr penelitian. Sumber penelitian dapatt dibedakan menjadi duaa yaitu, bahan hukom primeer dan bahaan hukom sekunderr. ${ }^{18}$

\section{a. Bahan Hukum Primer}

Bahan hukum primerr merupakan bahan hokum yang bersiifat auto ratif, artinya yang berkepentingan, dengan kata lain mengikaat atau yang membuat orang taat pada hokum seperti peraturan perundang-undangan dan putusan hakim.

Bahan Hukum Primer yang digunakan dalam penulisan ini adalah:

1) Undang-Undang Dasar 1945

2) Undang-Undang No. 5 Tahun 1960 tentang Peraturan Dasar Pokok Pokok Agraria;

3) Undang-Undang Nomor 37 Tahun 2008 tentang ORI Republik Indonesia;

4) Peraturan Pemerintahh No. 24 Tahun 1997 tentang Pendaftran Tanahh; 
5) Peraturan Presiden No. 20 Tahun 2015 tentang Badan Pertanahhan Nasional.

b. Bahan Hukm Sekunder

Bahan sekunder merupakan semiua edaran tentang hokum yang bukan merupakian berkas berkas resmii. Publikasi tentang hukum meliputi buku -buku teks, dictionary of law, jurnal -jurnal law, dan komentarkomentar atas putusan pengadilan. Bahan Hukum Sekunder yang digunakan dalam penulisan ini adalah: Buku -bukuu yang berkaitan dengan isu huukum yaitu tentang Hak - Hak ataas tanahh dan cara Pendaftran tanahh, Artikel yang berkaitan dengan isu hukum yaitu mengenai ORI, Bahan bahan lainya yang berkaitan dan dengan adanya pencarian data melalui internet mengenai ORI.

c. Bahan Non hukum

Bahan n0n hukuum adalah bahan yang tidak termasuk bahan primer dan bahan sekunder tetapi mempunyai kaitan atau dapat mempunyai kemampuan untuk mengidentification dan menganalisiss fakta untuk dapat menemukan and menyelesaikan isu hukom. Bahan nonhukum yang digunakaan dalam penulisaan ini adalah: Surat kabar and Pencarian data di internet

\section{Pendekatan Penelitian}

Metode pendekatann yang digunakan adalah pendekatan perundangundagan, Pendekatan undang - undang (statute approach) dilakukan dengan menelaah semua undang - undang dan peraturan yang bersangkut paut dengan isu hukumm yang sedang diurus. ${ }^{19}$ Selain Metode

\footnotetext{
${ }^{19}$ Peter, Op.Cit., hal. 131.
} 
pendekatan perundang- undangan, peneliti juga memakai Metode pendekatan case. Metode Pendekatan case dilakukan dengan cara melakukan telaaah terhadap peristiwa hukum yang berkaitan dengan isuu yang dihadapi yang telah menjadi putusan pengadilan yang telah mempunyai kekuatan tetap. ${ }^{20}$

Metode pendekatan perundang-undangan dan metode pendekatan kasus digunakan dalam penelitian ini karena merupakan metodeh pendekatn yang paling tepat dalam memecahkan masalah isu hukum yang sedang dikaji, dalam hal ini isu hukum penelti yang sedang dikaji adalah Keabsahan Sertipikat Hak Milik dan Hak Guna Bangunan yang dinyatakan maladministrasi oleh ORI.

5. Teknik Analisis Bahan Hukum

Teknik analisis bahan hukum, peneliti menggunakan teknik deskriptif dengan maksud peneliti memaparkan aapa adanya tentang suatu peristiwa hukom atau k0ndisi hukum. Peristiwa hokum adalah peristiwa yang beraspeek hukumm, terjadi di suatu tempat tertentu atau waktu ttertentu. ${ }^{21}$

\section{PEMBAHASAN}

A. Bagaimana Keabsahaan Sertipikat Hak Milik menurut UUPA dan Peraturan Pemerintahh Nomor 24 Tahun 1997 terkait pernyataan maladministrasi oleh ORI?

Sebelum membahas mengenai keabsahaan sertipikat tanahh yang dinyatakan maladministrasi oleh ORI Republik Indonesia pada pulau pari, peneliti akan menjelaskan yang merupakan dasar bagi analisis permasalahan ini

\footnotetext{
${ }^{20}$ Ibid., hal. 134.

${ }^{21}$ Dr. I Made, Op.Cit., hal. 152.
} 


\section{遭 Jurnal Huknum Adigamä}

Emeralda Leticia \& Hasni

Keabsahan Sertipikat

Hak Milik Atas Tanah Berdasarkan

UUPA dan Peraturan Pemerintah

Nomor 24 Tahun 1997

tentang Pendaftaran Tanah

yaitu tanahh. Tanahh dalam pengertiannya dibagi menjadi dua yaitu: dalam pengertian segi sempit atau pengertian segi luas. Pengertian segi sempit tanahh merupakan permukaan bumi, dan dalam pengertian segi luas tanahh juga dapat disamakan dengan agraria secara sempit.

Pengertian Agraria secara luas sendiri diatur dalam UUPA, yaitu : peraturan yang mengatur tentang earth, water, udara, space dan serta earth richness yang terdapat didalamnya. Agraria secara luas dan sempit sendiri diatur di dalam UUPA.Selain pengertian atas tanahh, terdapat juga teori hak hak atas tanahh yang harus diketahui dalam proses Pendaftran ini, teori hak hak penguasaaan atas tanahh. Hak - hak penguasaan atas tanahh terdiri menjadi empat yait: yang teratas adalah Hak Bangsa Indonesiaa, Hak menguasai dari Negra, Hak ulayat masyarakat adaat, hak hak seseorang

Hak Bangsa Indonesia merupakan hak tertinggi, daripada hak-hak lainnya, berdasarkan Bpk. Boedi Harsono, Hak Bangsa Indonesia merupakan sumber bagi hak penguasan lainnya serta Hak Bangsa Indonesia terbagi menjadi duaa unsur yaitu unseur kepunyan dan unsur tugas kewenangan. Unseur kepunyan yang mengartikan subjeknya adalah seluruh rakyat indonesia dan yang menjadi objeknya adalah seluruh wilayah Indonesia. Unsur tugas kewenangan adalah tugas untuk mengatur penguasaan dan memimpin pengurusan yang dilakukan oleh negara.

Hak Menguasaei dari Negara terdapat dalam Pasal 2 ayat (2) UUPA yang berupa mengatur serta menyelengarakan pemeliharaan bumi, air and ruang angkasa. Berdasarkan Pasal 2 ayat (3) UUPA dijelaskan bahwa wewenang yang diberikan digoenakan untuk mencapai sebesar-besarr kemakmuran rakyat dalam arti kebangsaan, kesejahteraan dan kemerdekaan dalam masyarakat dan Negara hukum Indonesia yang merdeka, berdaulat, adil dan makmur.Hak 


\section{:-: Jurnal HuGum Adigamä}

Emeralda Leticia \& Hasni

Keabsahan Sertipikat Hak Milik Atas Tanah Berdasarkan UUPA dan Peraturan Pemerintah Nomor 24 Tahun 1997 tentang Pendaftaran Tanah

menguasai dari Negara ini memberikan kuasa kepada masyarakat berdasarkan Pasal 2 ayat (4) UUPA pelaksanaannya dapat dikuasakan kepada daerah-daerah adat dan masyarakat-masyarakat hukum adat, sekedar diperlukan dan tidak bertentangan dengan kepentingan nasional oleh karena itu disebut juga Hak Ulayat Masyarakat Hukum Adat.

Hak ulayat masyarakat hukm adaat ini tetap berlaku selama masih ada dan tidak bertentangan dengan undang-undang dan peraturan yang lebih toenggi dari Hak ulayat tersebut memberikan hak perseorangan untuk mengelola tanahh asal tidak bertentangan dengan peraturan yang lebih tinggi. Hak-hak perorangan/individual terbagi menjadi 3 yaitu: Hak-hak atas tanahh, wakaf dan Hak jaminan atas tanahh. Hak-hak atas tanahh sebagai hak-hak perseroangan yang baik secara langsung ataupun tidak langsung bersumber pada Hak Bangsa. Wakaf adalah Perbuatan hukum merubah status Hukum menjadi Tanahh Wakaf untuk keperluan peribadahahan menurut syariat islam. Wakaf sendiri diatur dalam Pasal 49 UUPA ayat (3) dan Peraturan Pemerintahh Nomor 28 Tahun 2018.

Dalam rangka menyusun kepastian hukum dalam pendaftran tanahh, Peneliti dalam hal ini menggunakan pendaftran tanahh secara spoeradik karena kasus yang digunakan dalam peneliti ini menggunakan Pendaftran tanahh secara sporadik, selain sistemnya dalam Pendaftran juga terdapat beberapa asas-asas yang harus diterapkan. Kegiatan pengukuran ini terdapat dalam Pasal 20 PP No. 24 Tahun 1997 tentang Pendaftran tanahh, dalam hal ini wilayah yang melakukan Pendaftran secara sporadik dan belum terdapat peta Pendaftran maka dapat menggunakan peta yang lain yang sesuai.

Setelah dilakukannya pengukuran maka dilakukan pengumuman yang pengumuman setelah melakukan pengukuran di atur dalam Pasal 26 


\section{倦 Jurnal HuGum Adigamä}

Emeralda Leticia \& Hasni

Keabsahan Sertipikat

Hak Milik Atas Tanah Berdasarkan

UUPA dan Peraturan Pemerintah

Nomor 24 Tahun 1997

tentang Pendaftaran Tanah

Peraturan Pemeritnah No. 24 Tahun 1997. Tujuan dilakukannya pengumuman adalah untuk memberitahukan pemberitahuan mengenai hasil tanahh yang diukur. Berapa lama pengumuman juga tergantung dari sistem Pendaftran tanahh, jika menggunakan Pendaftran tanahh secara sistematik adalah 30 (tiga pouluh) hari dan 60 (enam puluh) hari untuk Pendaftran tanahh secara sporadik. Setelah diumumkan selama 60 hari dalam Pendaftran tanahh secara sporadik untuk mengajukan keberatan, jika tidak ada yang mengajukan keberatan maka akan dilakukan pengesahan dalam bentuk berita acara yang bentuknya ditetapkan oleh Menteri. Dalam berita acara pengesahaan yang dimaksud digunakan untuk sebagai pembukuan hak atas tanahh yang bersangkutan dalam buku tanahh; pengakuan hak atas tanahh; pemberian hak atas tanahh. Hal ini diatur dalam Pasal 28 ayat (3) PP No. 24 Tahun 1997.

Pengesahan berita acara menjadi dasar dalam pembukuan hak atas tanahh yang kemudian akan dihasilkan sertipikat tanahh. Sertipikat tanahh diatur dalam Pasal 31 ayat (1) PP No. 24 Tahun 1997. Sertipikat tanahh diterbitkan untuk pemegang yang bersangkutan sesuai dengan data fisik dan data yuridis yang telah didaftar dalam buku tanahh. Sertipikat adalah surat tanda bukti hak yang kuat serta berlaku sebagai alat pembuktian yang kuat dan memuat data fisik dan data yuridis, data fisik dan data yuridis yang sesuai dengan data yang terdapat dalam surat ukur dan buku tanahh. Sertipikat terdapat dalam Pasal 32 ayat (1) PP No. 24 Tahun 1997 tentang Pendaftran tanahh.

Dalam kasus ini peneliti mendapatkan dua pendapat yang berbeda antara para pihak, peneliti mewawancarai Lembaga hukum Jakarta sebagai penerima kuasa dari warga pulau pari dan hasil wawancara dengan Kantor Kepala Pertanahhan Jakarta Utara sebagai pihak yang bersangkutan. Peneliti dalam hal ini akan menjelaskan secara singkat hasil dari penelitian ini, bahwa dalam hasil 
wawancara dengan para pihak yang bersangkutan yaitu Lembaga Hukum Jakarta menyatakan bahwa warga pulau pari tidak mengetahui adanya proses pengukuran dalam Pendaftran tanahh yang dilakukan oleh instansi yang berwenang atas permintaan pihak ketiga.

LBH Jakarta menyatakan dan disertai juga dengan Laporan Akhir Hasil Pemeriksaaan ORI Republik Indonesia menyatakan bahwa pada awalnya warga tidak mengetahui bahwa tanahh yang mereka tinggal sekarang telah hilang, mereka mengetahui telah kehilangan tempat tinggal dari mereka digusur untuk meninggalkan tempat tinggal yang mereka tinggali sejak nenek buyut mereka. Warga tidak mengetahui bahwa tanahh mereka telah didaftarkan secara sporadik, dan warga yang berbatasan dengan tanahh yang didaftarkanpun tidak mengetahuinya ada proses pengukuran sehingga tidak adanya persetujuan warga yang bersangkutan dan warga tidak memberikan persetujuan terhadap batas batas bidang tanahh yang diukur.

Lembaga Hukum Jakarta mengatakan bahwa dalam kasus pulau pari tidak dilakukan pengukuran yang dimana sertipikat tersebut tidak sah dan terdapat cacatnya administrasi. Jika tidak terjadinya pengukuran maka asas asas pengukuran tersebut juga tidak dilaksanakan.

Warga juga tidak mengetahui adanya hasil pengumuman, lebih tepatnya berdasarkan hasil laporan ORI dan wawancara dengan kuasa dari pulau pari. Bahwa berdasarkan hasil pemeriksaan bahwa Kantor Pertanahhan Kota Administrasi Jakarta Utara tidak mengumumkan hasil pengukuran dan peta bidang-bidang tanahh, sehingga warga tidak mengetahui dan tidak memiliki kesempatan untuk melakukan keberatan terhadap hasilpengukuran dan peta bidang-bidang tanahh. 
Peneliti setuju akan pendapat dari kuasa warga pulau pari, yaitu LBH Jakarta. Dalam hal ini, jika tidak dilakukan pengukuran maka tidak dilakukan Pendaftran tanahh, secara dalam hal ini dinyatakan dilakukan Pendaftran tanahh secara sporadik yang berarti tidak ada hak yang melekat pada tanahh tersebut ataupun sertipikat dalam tanahh tersebut. Pendaftran yang tidak dilakukan pengukuran serta pengumuman membuat data tersebut menjadi tidaklah valid untuk digunakan karena tidak adanya persetujuan akan hasil pengukuran dan warga juga tidak mengetahui adanya proses pengukuran. Salah satu prosedur dalam mendaftarkan tanahh adalah mendapatkan data fisik, jika tidak dilakukan pengukuran maka tidak terlaksanakan Pasal 14 PP No. 24 Tahun 1997, yang dimana untuk mendapatkan dan menggunakan data fisik harus dilakukannya pengukuran tanahh yang berkaitan dengan data fisik tersebut. Serta dalam pengukuran tanahh juga terdapat asas contradictoire delimitatie yang menyatakan bahwa para pihak yang berbatasan harus mengetahui letak batas yang akan diukur. Asas ini bertujuan untuk mengurangi adanya kesalahan dalam pengukuran. Dalam hal ini tidak dilakukan pengukuran maka data fisik yang digunakan jugalah tidak valid serta tidak adanya persetujuan antara para pihak yang berbatasan membuat pengukuran tersebut telah melanggar Pasal 14 ayat (1) PP No. 24 Tahun 1997.

Seperti hasil wawancara diatas diberitahukan juga bahwa tidak dilakukannya pengumuman yang merupakan hasil pengukuran, dalam hal ini tidak dilakukannya pengumuman maka berarti tidak memberikan kesempatan untuk mengajukan keberatan. Hasil pengukuran sendiri harus diumumkan melalui pengumuman yang terdapat di kantor kelurahan ataupun kantor pertanahhan. Hasil pengukuran diumumkan selama 60 hari jika melakukan Pendaftran tanahh secara sporadik. Dalam hal ini tidak dilakukan pengumuman telah melanggar Pasal 26 ayat (1) PP No. 24 Tahun 1997, Pasal 26 ayat (1) PP No. 24 Tahun 1997 mengatur 
mengenai hasil pengukuran diumumkan untuk berapa hari dan tujuannya dilakukan pengumuman adalah untuk memberikan kesempatan untuk mengajukan keberatan. Peneliti dalam hal ini juga telah melakukan wawancara dengan para pihak yang bersangkutan yaitu Kepala Kantor Pertanahhan Jakarta Utara bahwa semua yang dinyatakan oleh Lembaga Hukum Jakarta dan Lahp ORI tidak begitu adanya. Pihak dari Kantor Pertanahhan Jakarta Utara atau disingkat sebagai BPN Jakarta Utara menyatakan bahwa mereka melakukan pengukuran dengan menunjukkan surat ukur kepada peneliti, dimana terpapar dengan jelas surat ukur dan peta bidang-bidang tanahh tersebut. Surat Pengumuman juga dipaparkan didepan peneliti dan menjelaskan bahwa mereka melakukan pengumuman dikantor lurah di wilayah pulau pari dengan bukti yang mereka tunjukkan tetapi peneliti tidak dapat memberikan buktinya karena itu merupakan data milik negara yang memiliki privasi orang.

Dalam wawancaranya pihak kantor pertanahhan Jakarta utara menyatakan bahwa mereka hanya mengikuti prosedur saja. Setiap prosedur mereka jalankan serta berdasarkan permintaan pihak yang berkepentingan untuk mendaftarkan tanahh yaitu Pendaftran sporadik. Peneliti kurang setuju, bahwa benar mereka telah melakukan sesuai dengan prosedur yang diterapkan dengan Peraturan Pemerintahh No. 24 Tahun 1997 tentang Pendaftran tanahh tetapi mereka tidaklah menerapkan prinsip kehati-hatian yang artinya mereka tidak mencari tahu kebenaran atas berkas berkas yang diberikan serta tanahh yang dijadikan objek pendaftaran.

Pendaftran tanahh secara sporadik berarti Pendaftran tanahh yang dilakukan berdasarkan kepentingan pihak yang berarti pihak yang berkepentingan akan memberikan berkas yang diperlukan. Tugas BPN disini merupakan Pendaftran tanahh tetapi dengan mencari tahu kebenaran atas objek tersebut 
sehingga memberikan jaminan kepastian kepada pemegang sertipikat dan tidak terjadi kerugian bagi pemilik tanahh yang sebenarnya.

Dalam hal ini terdapat dua pendapat yang berbeda dimana satu pihak menyatakan bahwa terjadinya maladministrasi pulau pari dan di satu pihak menyatakan bahwa mereka telah melakukan sesuai dengan ketentuan Peraturan Pemerintahh No. 24 Tahun 1997 tentang Pendaftran tanahh. Dalam menerbitkan sertipikat tanahh, dalam hal ini belum terdapat sertipikat sebelumnya maka akan dilakukan Pendaftran yang prosedur Pendaftran telah dijelaskan diatas sedemikian rupa. Sertipikat tanahh sendiri merupakan bukti kepemilikan hak yang kuat.

Sertipikat jika dinyatakan maladministrasi berarti terdapat penyimpangan prosedur dalam Pendaftran tanahh, Pendaftran tanahh di kasus ini menggunakan Pendaftran tanahh sporadik. Pendaftran tanahh secara sporadik adalah Pendaftran tanahh yang diajukan oleh pihak yang berkepentingan. Pendaftran tanahh baik secara sporadik ataupun sistematik harus dilakukan pengukuran dan pengukuran tanahh tersebut harus diketahui oleh warga yang berbatasan dengan tanahh yang akan diukur serta memiliki tanda tangan mereka atau persetujuan mereka ataupun jika terdapat keberatan maka setidaknya warga yang berbatasan mengetahuinya karena itu juga merupakan inti dari asas contradictoire delimitatie. Pengukuran tanahh yang harus diketahui oleh para pihak yang berbatasan juga terdapat dalam Pasal 17 ayat (2) yang menyatakan "Dalam penetapan batas bidang tanahh pada Pendaftran tanahh secara sistematik dan Pendaftran tanahh secara sporadik diupayakan penataan batas berdasarkan kese-pakatan para pihak yang berkepentingan."

Pasal 18 ayat (1) menyatakan : "Penetapan batas bidang tanahh yang sudah dipunyai dengan suatu hak yang belum terdaftar atau yang sudah terdaftar tetapi 
belum ada surat ukur/gambar situasinya atau surat ukur/gambar situasi yang ada tidak sesuai lagi dengan keadaan yang sebenarnya, dilakukan oleh Panitia Ajudikasi dalam Pendaftran tanahh secara sporadik, berdasarkan penunjukan batas oleh pemegang hak atas tanahh yang bersangkutan dan sedapat mungkin disetujui oleh para pemegang hak atas tanahh yang ber-batasan."

Penetapan batas bidang tanahh harus mendapatkan persetujuan berdasarkan Pasal 18 ayat (4) menyatakan bahwa persetujuan dituangkan dalam suatu berita acara yang ditandatangani oleh mereka yang memberikan persetujuan. Jika tidak terdapat persetujuan maka berdasarkan Pasal 19 ayat (1) menyatakan bahwa jika tidak terdapat persetujuan antara kedua belah pihak mengenai penetapan batas bidang tanahh maka pengukuran tanahhnya diupayakan untuk sementara berdasarkan batas batas yang bersangkutan. Jika para pihak tidak dapat menghadirinya atau belum mendapatkan kesepakatan batas maka akan dilakukan berita acara mengenai pengukuran sementara.

Persetujuan atas pengukuran tanahh harus diumumkan sesuai dengan sistim pendaftarannya yang diatur juga dalam Pasal 26 ayat (1) menjelaskan bahwa peta bidang atau hasil pengukuran diumumkan selama 30 (tiga puluh) hari dalam Pendaftran tanahh secara sistematik atau 60 (enam puluh) hari dalam Pendaftran tanahh secara sporadik untuk memberikan kesempatan kepada pihak yang berkepentingan mengajukan keberatan. Jika dalam prosedur Pendaftran tanahh tidak dilakukan atau menyimpangi pasal pasal yang telah dijelaskan demikian maka dianggap telah cacat hukum karena tidak sesuai dengan tata cara Pendaftran tanahh berdasarkan PP No. 24 Tahun 1997 tentang Pendaftran tanahh.

Telah diatur juga dalam Pasal 32 ayat (2) dalam hal atas suatu bidang tanahh sudah diterbitkan sertipikat secara sah atas nama subjek hukum yaitu orang ataupun badan hokum yang memperoleh tanahh tersebut dengan maksud baik dan 
secara nyata dalam lapangan menguasainya, maka pihak lain yang merasa mempunyai hak atas tanahh itu tidak dapat lagi menuntut pelaksanaan hak tersebut apabila dalam jangka waktu 5 (lima) tahun sejak diterbitkannya sertipikat itu telah tidak mengajukan keberatan secara tertulis kepada pemegang sertipikat serta Kepala Kantor Pertanahhan yang bersang-kutan ataupun tidak mengajukan gugatan ke Pengadilan mengenai penguasaan tanahh atau penerbitan sertipikat tersebut.

\section{B. Konsekuensi hukum bagi pemegang sertipikat akibat pernyataan maladministrasi}

Peneliti harus menjelaskan terlebih dahulu sebelum ke inti permasalahan. Di dalam Pendaftran tanahh terdapatnya sistem Pendaftran tanahh. Sistem Pendaftran Tanahh ada dua sistem Pendaftran tanahh, yaitu sistem Pendaftran akta dan sistem Pendaftran hak.

Sistem Pendaftran akta digunakan oleh negara negara yang menggunakan sistem civil law, seperti Negara belanda dan Eropa kontinental lainnya sedangkan sistem Pendaftran hak digunakan oleh negara yang menggunakan sistem common law, salah satunya adalah Negara inggris. Sistem Pendaftran akta adalah sistem Pendaftran yang didaftarkan adalah akta-akta yang bersangkutan dan disini pejabat Pendaftran tanahh bersifat pasif. Pasif disini yang mengartikan bahwa pejabat Pendaftran tanahh tersebut tidak melakukan pengujian kebenaran data yang terdapat dalam akta yang akan didaftarkan. Tanda bukti haknya merupakan salinan akta yang sudah dibubuhi catatan Pendaftran dan surat ukur. Perubahan akan hak wajib dibuatkan akta Notaris sebagai buktinya. Jika terdapat cacat hukum maka akan mengakibatkan tidak sahnya perbuatan hukum.

Sistem Pendaftran hak adalah sistem Pendaftran yang didaftarkan adalah 


\section{:-: Jurnal HuGum Adigamä}

Emeralda Leticia \& Hasni

Keabsahan Sertipikat

Hak Milik Atas Tanah Berdasarkan

UUPA dan Peraturan Pemerintah

Nomor 24 Tahun 1997

tentang Pendaftaran Tanah

haknya. Hak yang didaftarkan tersebut terdapat dalam suatu daftar isian, yang disebut juga dengan Buku Tanahh (Register). Akta pemberian hak merupakan sumber untuk data yuridis dalam mendaftarkan hak yang terdapat dalam Buku Tanahh. Buku Tanahh juga memuat mengenai pemindahan hak atau pembebanan hak atau segala sesuatu yang terdapat perubahan-perubahan hak maka terdapat dalam buku tanahh yang bersangkutan. Dalam hal ini terdapat perbedaan antara Sistem Pendaftran Akta dan Sistem Pendaftran Hak. Sistem Pendaftran akta pejabatnya bersifat pasif, maka sistem Pendaftran hak merupakan kebalikan dari sistem Pendaftran akta karena di dalam sistem Pendaftran hak pejabatnya bersifat aktif. Aktif disini adalah pejabat mencari tahu kebenaran yang dilakukannya pengujian kebenaran akta yang dimuat didalam akta yang bersangkutan.

Indonesia, dalam hal ini menggunakan sistem Pendaftran hak yang dianut oleh Peraturan Pemerintahh Nomor 24 Tahun 1997 tentang Pendaftran Tanahh. Dalam Pasal 19 UUPA tertulis bahwa Pendaftran tanahh meliputi pengukuran perpetaan dan pembukuan tanahh; Pendaftran hak-hak atas tanahh dan peralihan hak-hak tersebut; dan pemberian surat-surat tanda bukti hak, yang berlaku sebagai alat pembuktian yang kuat.

Pasal 19 UUPA ini telah menjelaskan secara jelas bahwa Indonesia menganut Sistem Pendaftran hak dengan menyatakan bahwa terdapat pembukuan tanahh atau juga disebut dengan register serta terdapat Pendaftran hak yang telah menjadi identitas dari sistem Pendaftran hak serta terdapat suratsurat tanda bukti hak yang merupakan sertipikat sebagai alat pembuktian yang kuat. Setelah sistem Pendaftran tanahh terdapat juga yang disebut sebagai sistem publikasi. Sistem publikasi terbagi menjadi dua yaitu sistem publikasi negatif dan sistem publikasi positif. Sistem publikasi negatif adalah sistem yang 


\section{:-: Jurnal Hußnum Adigamå}

Emeralda Leticia \& Hasni

Keabsahan Sertipikat

Hak Milik Atas Tanah Berdasarkan

UUPA dan Peraturan Pemerintah

Nomor 24 Tahun 1997

tentang Pendaftaran Tanah

disebut negatif karena negara tidak bertanggung jawab atas hasil akhir dari pejabat negara yang dimana jika terdapat cacat hukum dalam akta tersebut maka dapat dibatalkan negara yang menganut sistem ini salah satunya adalah negara Belanda. Sistim Publikasi Negatif menghasilkan sertipikat yang tmerupakan tanda bukti hak atas tanahhnya yang kuat yang berarti semua penjelasan yang terdapat di dalamnya mempunyai kekuatan hukum dan harus diterima sebagai penjelasan yang benar oleh hakim dan jika tidak ada yang membuktikan sebaliknya. Sistem publikasi negatif digunakan oleh negara yang menganut sistem civil law yaitu Negara belanda dan Eropa kontinental dan kebanyakan dari negara tersebut menggunakan Pendaftran akta. Sistem publikasi positif digunakan oleh negara yang menganut sistem common law yaitu negara inggris dan negara tersebut menganut sistem Pendaftran hak.

Sistem Publikasi Positif adalah yang dimana negara bertanggung jawab atas kesalahan dari pejabat yang mengakibatkan kerugian bagi para pihak dan jika terbukti adanya kesalahan dari pejabat maka negara akan membayar ganti rugi atas kelalaian tersebut. Akta tanahh yang didaftarkan dalam sistem publikasi positif bukanlah berkuatan kuat tetapi berkuatan tetap atau mutlak yang artinya tidak dapat diganggu guggat. Jika terdapat kesalahan yang dibuat dan merugikan pihak lainnya akan diberikan kompensasi atau ganti rugi dalam bentuk lain.

Berdasarkan hasil interview dengan salaah satuu pihak yaitu pihak LBH Jakarta, konsekuensi akibat mal administrasi sertipikat tersebut adalah pihak yang berwenang untuk mencabut kembali sertipikat tersebut serta dinyatakan tidak berlaku. Pihak LBH Jakarta menjelaskan dengan alasan tidak dilakukan sesuai dengan proses Pendaftran tanahh menurut PP No. 24 Tahun 1997. Berdasarkan penjelasan oleh pihak LBH Jakarta, peneliti setuju akan 
pendapatnya karena Indonesia menganut sistem publikasi negatif, yang berarti akta itu berkekuatan kuat selama tidak dapat dibantahkan. Jika dapat dibantahkan bahwa terdapatnya kelalaian maka akta itu dianggap cacat hukum atau juga disebut maladministrasi.

Dalam hal ini dapat dibuktikan bahwa Indonesia menganut sistem publikasi negatif dengan mengacu pada Pasal 32 ayat (2) PP No. 24 Tahun 1997 yang menjelaskan Pendaftran tanahh menghasilkan surat tanda bukti hak yang berlaku sebagai pembuktian yang kuat, bukanlah sebagai alat pembuktian yang mutlak (sistim negatiif). Dalam hal ini peneliti telah menjelaskan bahwa Indonesia menganut sistem Pendaftran hak dengan publikasi negatif, yang artinya bahwa sertifikat tersebut berkekuatan kuat dan tidaklah mutlak oleh karena itu para pihak yang dirugiikan akibat maladministration atao cacat hokum dapat mengajukan keberatan terhadap pejabat yang melakukan Pendaftran tanahh.

Para pihakk yang telah dirugiikan akibat maladministration atau cacat hukum dapat mengajukan keberatannya ke pejabat negara yang berwenang yaitu melalui ke Pengadilan Tata Usaha Negara. Dalam mengajukan gugatan ke pengadilan tata usaha negara yaitu dalam jangka waktu 90 hari setelah sertipikat itu dikeluarkan. Para pihak juga dapat mengajukan gugatan ke pengadilan negeri atas cacat hukum atas sertipikat tersebut, atau pihak yang dirugikan dapat mengajukannya karena indonesia menganut sistim publikasi negatiif yang menganut sertipikat berkekuatan kuat jika dapat dibantahkan maka sertipikat tersebut tidak berlaku selama belum ada putusan yang menguatkannya. Indonesia menganut sistim publiikasi negatif juga berarti negara tidak menjamin data fisik dan data yuridis oleh karena itu negara tidak memberikan ganti rugi tetapi sertipikat tersebut dapat berubah hak kepemilikannya berdasarkan 
kenyataan yang diputuskan oleh hakim. Para pihak juga dapat mengajukan keberatannya kepada ORI Republik Indonesia yang mempunyai kewenangan mengawasi penyelenggaraan pelayanan umum baikk instansi negeori ataupun swaasta, tugasnya ORI juga salah satunaya adalah menerima laporan atas dugaan maladministration dalam penyelenggaraan pelayanan umum.

\section{PENUTUP}

\section{A. Kesimpulan}

Berdasarkan penelitian yang telah dilakukan, Peneliti menyimpulkan bahwa tidak sahnya sertipikat tersebut dalam kasus keabsahan sertipikat hak milik atas tanahh berdasarkan UUPA dan Peraturan Pemerintahh Nomor 24 Tahun 1997 tentang Pendaftran Tanahh yang disebabkan oleh hal-hal sebagai berikut:

1. Berdasarkan Hasil Akhir Pemeriksaan ORI Republik Indonesia bahwa telah terjadi mal administrasi terhadap sertipikat hak milik beserta hasil wawancara yang menjelaskan bahwa adanya prosedur yang tidak dijalankan dalam prosess Pendaftran tanahh yang diatur dalam Peraturan Pemerintahh Nomor 24 Tahun 1997.

2. Penerapan prinsip kehati-hatian tidak dijalankan dengan semestinya oleh Kantor Pertanahhan Jakarta Utara, yang dimana prinsip kehati-hatian hanya dilakukan sebatas pemenuhan prosedur administrasi dan persyaratan formal, akibatnya terjadinya kehilangan tempat tinggal bagi para warga.

\section{B. Saran}

Pendaftran tanahh yang diatur berdasarkan Peraturan Pemerintahh Nomor 24 Tahun 1997 tentang Pendaftran tanahh. PP No. 24 Tahun 1997 telah mengatur secara jelas mengenai setiap prosedur yang akan dilakukan tetapi kesalahan dalam Pendaftran tanahh juga tidak akan luput. Bagi pihak yang merasa 
dirugikan atas diterbitkan sertifikat tersebut dapat melakukan gugatan ke pengadilan negeri ataupun menyatakan keberatan tersebut kepada ORI. ORI sendiri merupakan badan independen yang tugasnya adalah melakukan pengawasan yang hasil akhirnya adalah memberikan surat rekomendasi yang langsung dituju kepada Badan Eksekutif. Bagi Kepala Kantor Pertanahhan yang berkaitan untuk menghindari adanya gugatan dari pihak yang bersangkutan mengenai mal administrasi sertipikat tersebut. Dengan menerapkan prinsip kehati-hatian yang tidak hanya berpaku pada standart formal dan memenuhi administrasi saja tetapi juga di lakukan pengecekan secara lapangan dimana objek tersebut berada serta memerhatikan kepentingan para pihak yang berbatasan.

\section{DAFTAR PUSTAKA}

\section{A. Buku}

Asikin, H. Zainal dan Ammirudin, Pengantar Metode Penelitian Hukum. (Jakarta: PT Raja Grafindo Persada, 2006).

Harsono, Boedi, Hukum Agraria Indonesia. (Jakarta: Djambatan, 2008).

Diantha, I Made Pasek Diantha, Metode Penelitian Hukum Normatif dalam Justifikasi Teori Hukum. (Jakarta: Kencana Prenada Media Group, 2016).

Marzuki, Peter Mahmud. Penelitian Hukum. (Jakarta: Kencana Prenada Media Group, 2016).

Santoso, Urip. Hukum Agraria dan Hak-Hak Atas Tanahh, Cetakan ke-5. (Jakarta: Kencana Pranada Media Group, 2009).

Supriadi. Hukum Agraria. (Jakarta: Sinar Grafika, 2008).

Sugiyono. Metode Penelitian Pendidikan Pendekatan Kuantitatif, Kualitatif, dan $R \& D$. (Bandung: Alfabeta, 2013).

Sutedi, Adrian, Sertipikat Hak Atas Tanahh. (Jakarta: Sinar Grafika, 2014). 